\title{
The Role of Memory and Tradition in the Construction of Identity in the Nineteenth-Century Bahamas
}

\author{
Paul Farnsworth \\ Temple University, Philadelphia, USA
}

\begin{abstract}
Tradition has been defined as practices brought forward from the past into the present. In the context of enslavement and the cultural dislocation that accompanied it, memory became critical in the recreation of tradition. Individual memory contributed to the practices that created new traditions to be carried forward by subsequent generations. Archaeological evidence from Clifton Plantation, Bahamas, illustrates how memory and tradition shaped the identities of both enslaver and enslaved, and influenced the construction of an African Bahamian identity in the early nineteenth-century. In their consumer selections, the enslaved people of Clifton were constructing artifact assemblages that reflected their memories of their traditional cultural background. In the process they were creating an Afro-Bahamian aesthetic that would become a tradition for future generations of Bahamians. While the goods were not of their own manufacture, the choices were theirs from the selection available to them. At the same time, those of British heritage were signaling their British identity through their consumer choices. However, Clifton was unusual in being owned by a reformer who sought to ameliorate the conditions of slavery. The paper also briefly discusses whether these concepts are useful in understanding the material culture of enslaved Africans at other sites.
\end{abstract}

Keywords: African Diaspora, African-Bahamian identity, memory and tradition, historical archaeology, consumer choices

\section{Introduction}

When Africanist archaeologist Merrick Posnansky first visited Haiti in 1980, he said he "saw dispersed compounds in the hinterland. No simple detail of the construction was really West African, yet somehow the overall effect was uncannily so" (Posnansky, 1999, p. 32). When I first visited Jamaica a year later, I had a similar feeling, though not of West Africa, but of the England I grew up in. Many things were similar enough to bring back memories of home and my British background. Pauketat, in The Archaeology of Traditions, defines tradition as "some practice brought forward from the past into the present" (Pauketat, 2001, p. 4). In the context of enslavement and the cultural dislocation that accompanied it, memory of traditions became critical in the (re-)creation of tradition in the new geographic and social setting. Individual memory contributed to the practices that created new traditions to be carried forward by subsequent generations.

Historians, art historians, sociologists, anthropologists, and historical archaeologists are among the scholars who have looked at the large-scale impacts of the trans-Atlantic slave trade. Archaeology has established itself as

Paul Farnsworth, Ph.D., Professor, Department of Anthropology, Temple University.

Correspondence concerning this article should be addressed to Paul Farnsworth. 
an important avenue for exploring ethnogenesis, cultural change, and the construction of New World identities (e.g. Deagan, 1983; Farnsworth, 2001; Lightfoot, 1995; Lightfoot et al., 1997; Pauketat, 2001). Increasingly, archaeologists have turned to explorations of African-American material life (Deetz, 1993; Singleton, 1985, 1999; Wilkie, 2000, 2003; Yentsch, 1994). Much of the initial archaeological study of the development of Creole cultures in the Caribbean has focused upon the search for Africanisms, or the survival of different aspects of West African culture in the New World (e.g. Armstrong, 1990; Edwards-Ingram, 2001; Handler, 1996; Handler \& Lange, 1978; Haviser, 1999a, 1999b; Pulsipher, 1993). This research has been critical in establishing that enslaved Africans reconstructed aspects of their traditional lifestyles and beliefs despite the restraints of enslavement. Central to the study of Caribbean societies has been the nature of the African contribution to these cultures, and the ways that "race” becomes constructed (e.g. Gilroy, 1993; Gomez, 1998; Herskovits, 1971, 1990; Mama, 1995; Mintz, 1974; Mintz \& Price, 1976; S. Price \& R. Price, 1980, 1999; Thompson, 1974, 1983, 1993).

While it was once assumed that not enough persons from any particular ethnic group were transported together on any given slave ship, thus making the reproduction of any particular society impossible, scholars have now demonstrated that enslavers in different regions had specific preferences for individuals from particular ethnic groups, and acted intentionally to acquire those individuals (Creel, 1988; Gomez, 1998; Higman, 1998; Walsh, 1997). Certainly, it is possible to see in the material culture of the Caribbean, objects, words and practices that are identical to those seen in particular West African societies (e.g. Agorsah, 1994, 1999; Armstrong, 1990; Goucher, 1999; Handler, 1996; Handler \& Lange, 1978; Thompson, 1983; Vlach, 1986).

Scholars such as Sidney Mintz, Richard and Sally Price, and Douglas Armstrong (Armstrong, 1998, 2003; Mintz, 1974; Mintz and Price, 1976; S. Price \& R. Price, 1980, 1999) have argued that while certainly African-influenced, the cultures of the Caribbean are the result of transformative processes and particular histories that have led to the development of unique, dynamic, and constantly changing cultures. The search for Africanisms, they argue, merely serves to underemphasize the creativity and dynamism of the modern cultures by rendering them historically static. In their now classic 1976 study, Mintz and Price proposed that the process of creating new African-American cultures began at the point of capture in Africa, when enslaved people shared the trauma of the journey across the Atlantic. The process continued as individuals forged new communities as a way to survive the conditions of life in enslavement. Diaspora cultures, therefore, while African influenced, are not merely African-derived.

Gomez, in his 1998 study of Africans in the American South, has referred to this process as a shift from an ethnic identity to a racialized identity. Unlike Mintz and Price (1976), however, Gomez (1998) suggests that ethnic identities (and accompanying stereotypes that Europeans and other African groups held regarding one another) continued to shape relationships between enslaved people long after their arrival in the New World. In the Bahamas, as recently as the early 20th century, groups of African-descended Bahamians self-identified as members of competing African ethnic groups, practiced endogamous marriages, and spoke disdainfully of outsiders (Eneas, 1976).

Mintz and Price (1976) proposed that African cultures were not transplanted wholesale from the continent to the different parts of the Diaspora, and that evidence of specific continuities should not be necessarily seen as evidence of the associated social meaning and value transplanted cultural acts and materials may have had in their original cultural context. However, one can also envision African-American culture as being constructed from the social actor up. Persons brought with them, in memory, the things they valued: traditions, practices, ways of being and interacting with the world, senses of self, personhood, community and the cosmos. The construction of 
African-American society was a compromise between competing traditions; a compromise that was negotiated by social actors in dialog and in practice (Wilkie \& Farnsworth, 2005, p. 6). While it was not possible for an individual, or a small group of individuals, to replicate an entire social order, it was in their power to ensure that food is prepared in the proper way according to their traditions, that lived spaces were properly inhabited and maintained, that ancestors were remembered, and that family life maintained some sense of traditionally prescribed order. It was the collective traditions and behaviors of the smallest social units, the household, which became the basis for the construction of communal traditions (Wilkie \& Farnsworth, 2005, pp. 36-37).

Caribbean cultures, like that of the Bahamas, are the unique product of their place and time, and are fluid, dynamic, and subject to the ongoing creativity and innovation of the persons constructing those cultures. Ultimately, the shared experience of race-based enslavement served as a culturally defining and unifying experience for individuals from diverse cultural, ethnic and religious backgrounds. At the same time, there is evidence that individuals also continued to self-identify, in some cases, over multiple generations, by ethnic descent groups (Eneas, 1976).

To date, archaeologists have not adequately considered how the demographics of the slave trade shaped the specific populations that they are studying. Many scholars of the African slave trade have attempted to document its demographics (e.g. Behrendt, 1997; Curtin, 1972, 1976; Inikori, 1976; Manning, 1992). Intrinsic to this search are seemingly simple questions: who was taken from where, when, and by whom? Answering is not so easy, but an arena of intense study by Africanists and scholars of the Diaspora (e.g. Curtin, 1967, 1972, 1976; Eltis et al., 1999; Eltis \& Halbert, 2009; Higman, 1984; Inikori, 1976; Manning, 1992; Richardson, 1989). Scholars have used shipping and customs records, newspaper advertisements, colonial office records, and a variety of statistical models to attempt to construct the nature of the populations that moved between Africa and the New World. Records are not necessarily complete, nor complementary. What has been possible is to construct, in broad strokes, the contours and trends of the slave trade.

\section{African-Bahamian Origins}

Laurie Wilkie, my collaborator in the research at Clifton Plantation in the Bahamas, and I reconstructed the demographics of the slave trade to the Bahamas and recognized that distinct ethnic groups of Africans were brought in separate chronological waves (Wilkie \& Farnsworth, 2005, pp. 41-61). Africans came to the Bahamas during the Loyalist period, 1784-1835, in three primary ways: they were brought as enslaved people from the Carolinas and Georgia by the British Loyalists; they were brought directly from Africa to supply Loyalist plantations; or, they were seized from the Spanish as contraband by the British navy after the abolition of the trade in 1807 and then apprenticed on the islands.

The enslaved people brought by the Loyalists to the Bahamas from the Southeast were likely drawn from Senegambia, Sierra Leone, and Central Africa (Wilkie \& Farnsworth, 2005, pp. 44-46). Accompanying the African-born component of this enslaved population would have been their Creole children and grandchildren. While these younger generations had known no world other than the Americas, they came to the Bahamas with a communal memory of their African heritage and traditions. Archaeologists and ethnographers have demonstrated the rich influences of the Congo and Sierra Leone in the Carolinas and Georgia Sea Islands (e.g. Creel, 1988; Ferguson, 1992; Gomez, 1998; Joyner, 1984; Littlefield, 1981; Wilkie \& Farnsworth, 2005, p. 45).

For the slave trade to the Bahamas during the Loyalist period, Eltis, Behrendt, Richardson and Klein's 1999 database of the transatlantic slave trade was used, supplemented with material drawn from period 
Bahamian newspapers and Colonial Office Records. Our analysis identified 43 ships whose primary port of disembarkation was the Bahamas (Wilkie \& Farnsworth, 2005, pp. 41-48). These ships brought nine-and-a-half thousand enslaved people between 1786 and 1806 (Table 1), and of these it was possible to ascribe geographic origins to just over six thousand people. The majority was from Sierra Leone at 20\%, with more generically the Windward Coast an additional 3\% (Table 2). After Sierra Leone and the Windward Coast, Central Africa was the next largest proportion of the population, at 18\%, followed by peoples from the Bight of Biafra, at 15\%. Senegambia accounted for $5 \%$ of the trade (Wilkie \& Farnsworth, 2005, p. 55).

Table 1

The African Slave Trade to the Bahamas 1788-1807 (Compiled From Eltis et al. 1999)

\begin{tabular}{llll}
\hline Year & Number of ships & Number of people & $\begin{array}{l}\text { Geographic source } \\
\text { (not all ships' source could be identified) }\end{array}$ \\
\hline 1788 & 3 & 726 & Windward Coast, Angola \\
1789 & 1 & 72 & Windward Coast \\
1790 & 0 & 0 & Windward Coast \\
1791 & 1 & 64 & Sierra Leone \\
1792 & 1 & 210 & Sierra Leone \\
1793 & 1 & 216 & \\
1794 & 0 & 0 & Sierra Leone \\
1795 & 1 & 247 & \\
1796 & 0 & 0 & Not given \\
1797 & 1 & 233 & Senegambia \\
1798 & 1 & 91 & Senegambia, Windward Coast, Gold Coast, Sierra Leone \\
1799 & 3 & 476 & Sierra Leone \\
1800 & 3 & 528 & Sierra Leone \\
1801 & 4 & 1,066 & Bight of Biafra, Angola, Central Africa \\
1802 & 10 & 2,482 & Bight of Biafra, Central Africa \\
1803 & 8 & 2,013 & Sierra Leone, Angola, Central Africa \\
1804 & 3 & 638 & Central Africa \\
1805 & 1 & 341 & Senegambia \\
1806 & 1 & 157 & \\
1807 & 0 & 0 & \\
Total & 43 & 9,560 & \\
\hline
\end{tabular}

Table 2

Origins of Africans Brought to the Bahamas 1788-1807 (Compiled From Eltis et al. 1999)

\begin{tabular}{lll}
\hline Location in Africa & Number of people & Percentage of total \\
\hline Senegambia & 413 & 4.3 \\
Sierra Leone & 1,674 & 17.5 \\
Windward Coast & 258 & 2.7 \\
Gold Coast & 259 & 2.7 \\
Bight of Biafra & 2,283 & 23.9 \\
Central Africa & 1,390 & 14.5 \\
Not specified & 3,283 & 34.3 \\
\hline
\end{tabular}

People from Sierra Leone and Senegambia had been favored by Carolina slaveholders due to their expertise in rice cultivation, but their skill in salt production would have made them desirable in the Bahamas. While Loyalists went to the Bahamas to grow cotton, it was salt-raking, particularly on the southern Out Islands, which was the most stable economic product. The prevalence of Central Africans, many of whom were Congo 
based on their ports of embarkation, may also be the result of preferences formed by the Loyalists while living in the American South. Igbo, who were shunned in Georgia and the Carolinas, enter the Bahamas in large numbers only in 1802 and 1803, a time when enslaved people were purchased for their potential resale value in places like Havana, St. Augustine and New Orleans. An important consequence of the demographic pattern was that the transplanted Creole populations and the newly enslaved Africans brought to the Bahamas shared significant cultural traditions (Wilkie \& Farnsworth, 2005, pp. 58-59, 62).

\section{William Wylly}

William Wylly was born in Georgia in 1757 and in 1775 went to train in England to become a lawyer. He returned to America in 1780 to fight for the Crown in the Revolutionary War. In 1787, he was appointed Solicitor General of the Bahamas, and in 1799, he was appointed Attorney General of the Bahamas, staying until 1821 when he left for St. Vincent (Colonial Office Records [CO] 23/65:95; Craton \& Saunders 1992, p. 224). Wylly purchased the three parcels that make up Clifton plantation by 1809, totaling 791 acres (Figure 1) and developed it as his main estate (Wilkie \& Farnsworth, 2005, pp. 315-317). By 1821, he owned 67 enslaved people, most of them living on Clifton (Register of Slaves, 1821). Here, where Southern-born, enslaved people lived with African born, enslaved and apprenticed people, there were likely to have been people either directly or ancestrally from Sierra Leone, Senegambia, Benin, Congo and the Gold Coast. Wylly owned the plantation until his death in 1828, although most of the enslaved families were sold in the Bahamas in 1823 after he left for St. Vincent (Register of Slaves, 1825).

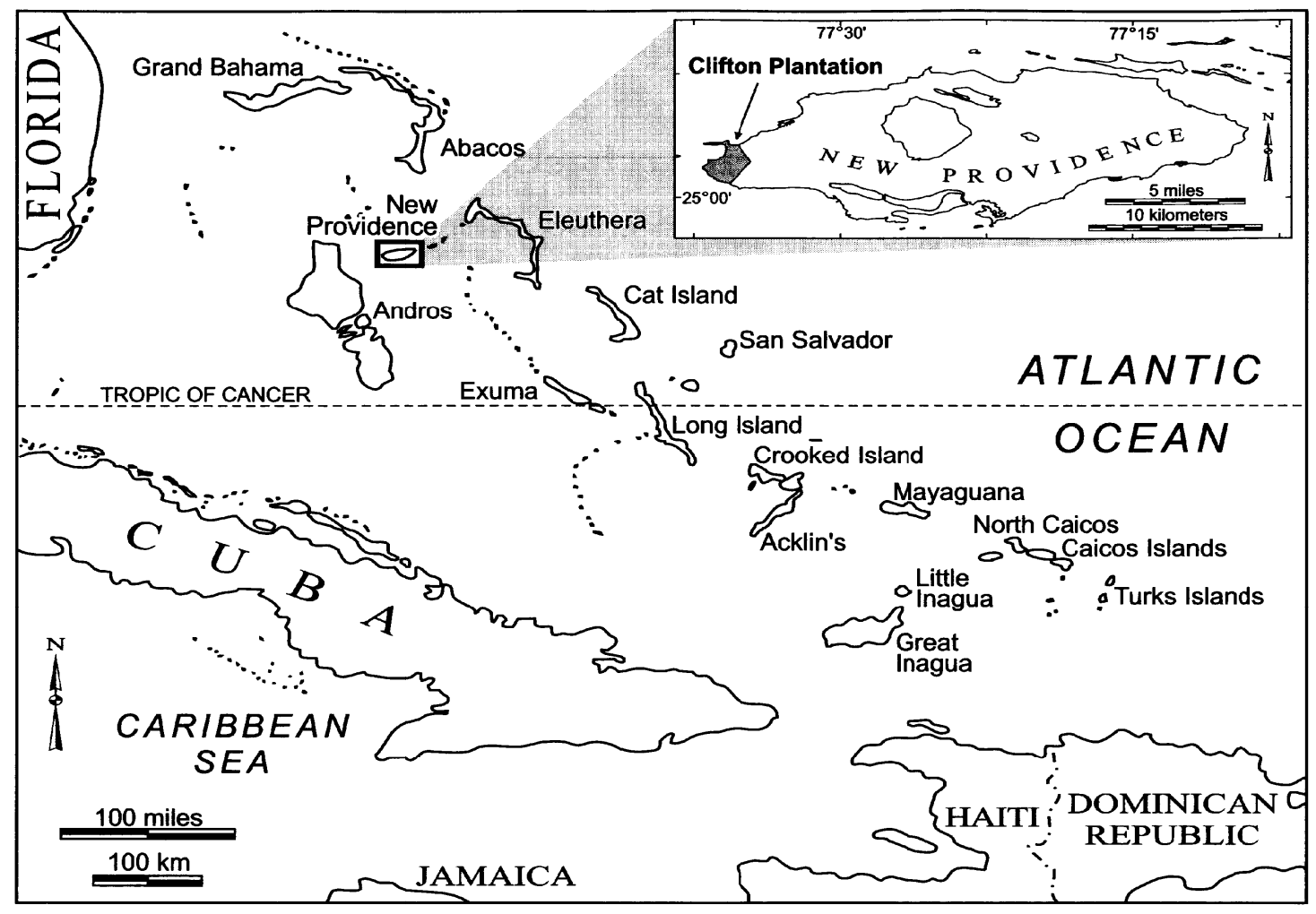

Figure 1. The location of William Wylly's Clifton Plantation.

Wylly was a fervent convert to Methodism, and developed Clifton as a social experiment, not as a wealth-producing enterprise. Wylly encouraged his enslaved people to be economically self-sufficient by 
providing several days a week for farming, transportation to the Nassau market, and paying wages for the completion of extra tasks (Wylly, 1815). These circumstances gave enslaved people at Clifton a rare degree of consumer autonomy, evidenced in both the diversity of goods contained within their household assemblages, and the inclusion of more luxury goods than ordinarily seen in enslaved families' assemblages (Wilkie \& Farnsworth, 2005, p. 75).

\section{Clifton Plantation}

\section{African Memories and Traditions}

From 1996 to 2000, Laurie Wilkie and I carried out archaeological excavations at 10 structures associated with the enslaved and apprenticed Africans who lived at Clifton (Figure 2), as well as at Wylly's main house and kitchen (Wilkie \& Farnsworth, 2005). Because of its short occupation, we were mainly looking at the material life of two generations: parents and their children. For the African population of the plantation, it is in this generational dynamic that the ethnogenesis of African-Bahamian culture took place. In everyday life and practice, the people of Clifton created traditions that united them as a community. Within that community, persons were defined and perceived according to their relationships to one another. The middle passage robbed individuals of the "social self" they had been in Africa, but they built a new "social self" in this community. Yet, there was still the "internal self"- the self that a person believes him or herself to be, based on their memories, traditions, and experiences (Wilkie \& Farnsworth, 2005, pp. 10-12).

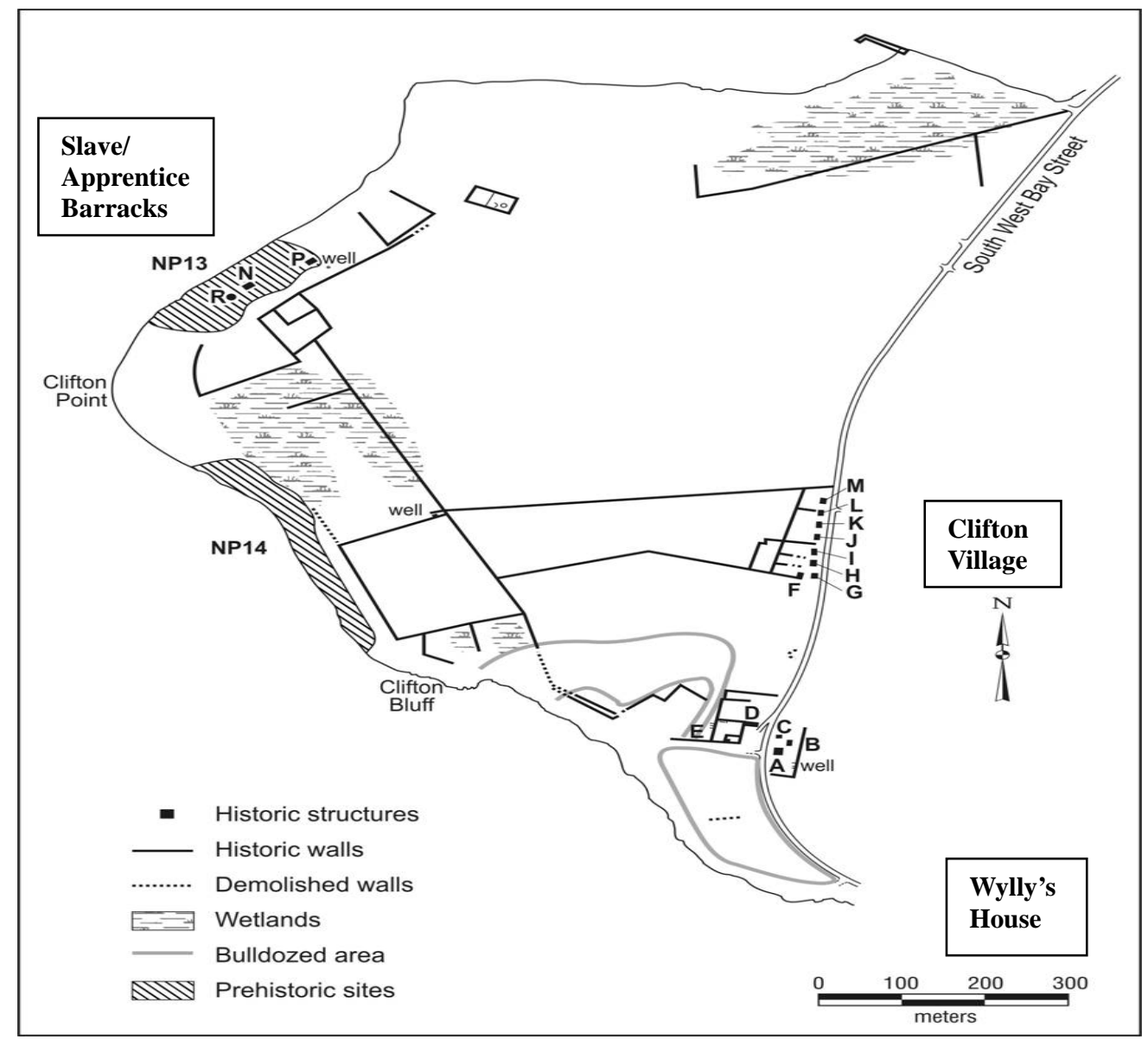

Figure 2. Clifton Plantation archaeological contexts. 
One aspect of African material culture reiterated by many Africanists is the vibrant creativity and innovation that continuously marks African cultural practice, whether in the performance of rituals or the construction of material culture (Jean Comaroff and John Comaroff, 1993; Posnansky, 1999; S. Price \& R. Price, 1999). Attempts to ascribe any pattern or style to an origin in a particular time or place risks missing the dynamism of artistic trends, but the collective aesthetic traditions of the diverse people who lived at Clifton was the potential universe of inspiration and knowledge that informed the construction of the material assemblages (Wilkie \& Farnsworth, 2005, p. 272).

I must emphasize at this point, that the ceramics found at Clifton were not made in Africa, nor by Africans, enslaved or apprenticed, in the Bahamas, but by British potters who shipped pottery to the Bahamas in response to orders placed by British merchants and planters. There was no tradition of ceramic manufacture by enslaved Africans in the Bahamas, no "colonowares" as they are often called (Ferguson, 1992). The ceramics from the African villages were either provided by the planters or obtained from merchants in Nassau through purchase or exchange, either directly, or more likely through intermediaries in the market at Nassau. Due to Wylly's liberal policies, including paying wages for extra tasks and providing access to the market in Nassau, the ceramic assemblages of the Clifton households were primarily the product of individual household consumer decision-making, not provisioning by the planter (Wilkie \& Farnsworth, 2005, pp. 254-256, 263-267).

In the market in Nassau, people of African birth and/or heritage were selecting from ceramics, and other products, made in England by British manufacturers. While the British potters were responsive to their customers in terms of providing more of what sold well, they were not designing or making pottery for African consumers, or with any knowledge or consideration of African culture. Africans were selecting from goods made for the British and Anglo North American markets. They had no control over the selection available. The British ceramics, and other artifacts for that matter, that they chose are indicative of the creation of a Bahamian aesthetic that was shaped, but not dictated, by memories of particular African aesthetic traditions.

In comparing the African village assemblages from Clifton, the importance of British-made factory-turned slipwares and hand-painted wares is noticeable (Table 3). Brown was the color most commonly found on these ceramic vessels in the village assemblages, often occurring on two-thirds or more of the vessels, with orange and green also occurring frequently (Table 4). Although blue was also common, it usually occurred on less than half of the vessels, and typically on about one-third of them. These particular kinds of British ceramics bear structural similarities in form, decoration, and color pallets, to pots, calabashes, and fabric designs popular among, and common to, the Congo, Windward Coast, Benin and Gold Coast peoples who are likely to have lived at Clifton (Wilkie \& Farnsworth, 2005, pp. 264-266, 273-277). The popularity of these particular decorative types seems to be an expression of an emerging African-Bahamian aesthetic tradition. 
Table 3

Percentage of Decorative Types of British Refined Earthenware Ceramics by Context

\begin{tabular}{|c|c|c|c|c|c|c|c|c|}
\hline \multirow[b]{2}{*}{ Decorative type } & \multirow[b]{2}{*}{$\begin{array}{l}\text { Wylly's } \\
\text { house } \\
\text { A }\end{array}$} & \multicolumn{5}{|c|}{ Clifton Village } & \multirow[b]{2}{*}{$\begin{array}{l}\text { - Slave/ } \\
\text { apprentice } \\
\text { barracks } \\
\mathrm{N}\end{array}$} & \multirow[b]{2}{*}{$\begin{array}{l}\text { Slave/ } \\
\text { apprentice } \\
\text { barracks } \\
\text { P }\end{array}$} \\
\hline & & $\begin{array}{l}\text { Slave } \\
\text { house/ } \\
\text { kitchen } \\
\text { F }\end{array}$ & $\begin{array}{l}\text { Driver's } \\
\text { house } \\
\text { G }\end{array}$ & $\begin{array}{l}\text { Slave } \\
\text { house } \\
\mathrm{H}\end{array}$ & $\begin{array}{l}\text { Slave } \\
\text { house } \\
\text { I }\end{array}$ & $\begin{array}{l}\text { Slave } \\
\text { house } \\
\text { L }\end{array}$ & & \\
\hline Plain \% & 18.8 & 22.5 & 16.7 & 18.2 & 23.0 & 14.3 & 48.6 & 50.0 \\
\hline Shell-edged \% & 25.0 & 10.0 & 18.5 & 10.9 & 19.2 & 21.4 & 21.6 & 10.0 \\
\hline Factory-turned \% & 6.3 & 22.5 & 16.7 & 16.4 & 28.8 & 21.4 & 2.7 & 20.0 \\
\hline Hand-painted \% & 18.8 & 22.5 & 24.0 & 43.6 & 11.5 & 32.1 & 21.6 & 0 \\
\hline Transfer-print \% & 31.3 & 22.5 & 20.3 & 7.3 & 17.3 & 10.7 & 2.7 & 10.0 \\
\hline Other \% & 0 & 0 & 3.7 & 3.6 & 0 & 0 & 2.7 & 10.0 \\
\hline Number of vessels & 16 & 40 & 54 & 55 & 52 & 21 & 37 & 10 \\
\hline
\end{tabular}

Table 4

Percentage of Hand Painted and Factory-Turner Slipware Ceramic Vessels on Which Colors Appear by Context

\begin{tabular}{|c|c|c|c|c|c|c|c|c|}
\hline \multirow[b]{2}{*}{ Color } & \multirow[b]{2}{*}{$\begin{array}{l}\text { Wylly's } \\
\text { house } \\
\text { A }\end{array}$} & \multicolumn{5}{|c|}{ Clifton Village } & \multirow[b]{2}{*}{$\begin{array}{l}\text { Slave/ } \\
\text { apprentice } \\
\text { barracks } \\
\mathrm{N}\end{array}$} & \multirow[b]{2}{*}{$\begin{array}{l}\text { Slave/ } \\
\text { apprentice } \\
\text { barracks } \\
\text { P }\end{array}$} \\
\hline & & $\begin{array}{l}\text { Slave } \\
\text { house/ } \\
\text { kitchen } \\
\text { F }\end{array}$ & $\begin{array}{l}\text { Driver's } \\
\text { house } \\
\text { G }\end{array}$ & $\begin{array}{l}\text { Slave } \\
\text { house } \\
\mathrm{H}\end{array}$ & $\begin{array}{l}\text { Slave } \\
\text { house } \\
\text { I }\end{array}$ & $\begin{array}{l}\text { Slave } \\
\text { house } \\
\text { L }\end{array}$ & & \\
\hline Blue \% & 60.0 & 33.3 & 38.1 & 42.3 & 29.4 & 46.6 & 53.8 & 0 \\
\hline Brown \% & 20.0 & 55.5 & 66.6 & 92.8 & 73.5 & 60.0 & 46.2 & 66.7 \\
\hline Green \% & 20.0 & 22.2 & 14.3 & 35.7 & 29.4 & 40.0 & 15.4 & 0 \\
\hline Orange \% & 0 & 22.2 & 14.3 & 17.8 & 8.8 & 20.0 & 15.4 & 0 \\
\hline Yellow \% & 40.0 & 16.7 & 47.6 & 60.7 & 41.2 & 46.6 & 15.4 & 33.3 \\
\hline Number of vessels & 5 & 18 & 21 & 28 & 34 & 15 & 13 & 3 \\
\hline
\end{tabular}

Note. Percentages do not add up to $100 \%$ as several colors may appear on the same vessel.

However, further consideration of these individual household assemblages also demonstrates great diversity in specific pattern choices. Ethnographic studies have shown the great variation and inventiveness that African women express through their selection of household goods-including pottery (Aniakor, 1996, p. 233). Others found that women and men alike take great pride in being innovative in their artistic pursuits, and value creativity in the work of others (S. Price \& R. Price, 1999; Wilkie \& Farnsworth, 2005, p. 282). When we look at the 10 African residences, we find that among the factory-turned slipwares and hand-painted ceramics alone, there are 20 patterns that are repeated between at least two houses, but 78 patterns that occur only in one household (Table 5). Among the four houses with the largest ceramic assemblages, no more than 53\% of the sherds at any house have the same designs as at any of the other households. For most of the houses, half or more of the patterns used were unique to them. If we look at overlap between any two households, we find no more than one-third of their patterns in common. The households shared a general tendency to select British ceramics decorated in similar ways and colors, but within that generality, specific color preferences and pattern choices were individualized by household. The great variation and inventiveness that was valued in African traditions was expressed through the selection of household goods. Although not of their own manufacture, the British ceramics and other consumer goods found at Clifton were material expressions of the creativity and personal style of the occupants, communicated in a traditional African way (Wilkie \& Farnsworth, 2005, p. 282). 
Table 5

Overlap in Hand-Painted and Factory-Turned Slipware Ceramic Patterns

\begin{tabular}{|c|c|c|c|c|}
\hline Locus & Unique patterns & Shared patterns & $\begin{array}{l}\text { Number of vessels decorated } \\
\text { with shared patterns }\end{array}$ & $\begin{array}{l}\text { Percentage of ceramics that } \\
\text { are shared patterns }\end{array}$ \\
\hline Slave house/kitchen F & 9 & 9 & 9 & 50 \\
\hline Driver's house G & 15 & 6 & 9 & 40.9 \\
\hline Slave house $\mathrm{H}$ & 21 & 12 & 13 & 38.2 \\
\hline Slave house I & 10 & 10 & 11 & 52.3 \\
\hline Slave house $\mathrm{J}^{*}$ & 1 & 0 & 0 & 0 \\
\hline Slave house $\mathrm{K}^{*}$ & 2 & 3 & 3 & 60.0 \\
\hline Slave house L & 10 & 5 & 5 & 33.3 \\
\hline Slave house $\mathrm{M}^{*}$ & 0 & 2 & 2 & 100.0 \\
\hline Slave/apprentice barracks N & 8 & 1 & 2 & 22.2 \\
\hline Slave/apprentice barracks $\mathrm{P}^{*}$ & 2 & 2 & 2 & 66.6 \\
\hline Total & 78 & 20 & - & - \\
\hline
\end{tabular}

Note. *assemblage had five or fewer vessels for this analysis.

Due to the large number of African-born individuals among the people of Clifton, the possibility that particular designs or symbols may have been consciously selected for their similarity to specific traditional African motifs or symbols cannot be ignored. The driver's house was occupied by Jack and Sue Eve. Both were African-born and lived with their two children (Wilkie \& Farnsworth, 2005, pp. 85, 92-95). In their assemblage, there is some evidence of how specific ethnic heritage could be communicated through British goods. While their assemblage shared many traits with the others, we identified several elements of their assemblage that may suggest a Central African or Congo heritage.

Other archaeologists and art historians have recounted the importance of the image of the cross as a possible symbolic short-hand for the Bakongo cosmogram in the Diaspora (e.g. Fennell, 2003, 2007, 2011; Ferguson, 1992, 1999, 2011; Gundaker, 1998, 2011; Joseph, 2011; Leone \& Fry, 1999; Thompson, 1981, 1983, 1993; Wilkie, 2001; cf. Steen, 2011). In its original form, the Bakongo cosmogram is a circle, quartered by an $\mathrm{X}$ with smaller circles on the end of each arm, which represent the four movements of the sun-the cycle of life and death, and the annual progression of the seasons. The driver's cabin contained an example of a British-made, hand-painted bowl featuring a design that evokes a Bakongo cosmogram on its interior base (Figure 3). On the sherd, the design is centered and may have been curated after the bowl broke (Wilkie \& Farnsworth, 2005, pp. 280-281). A likeness of the cosmogram is also found along the border of three other hand-painted bowls featuring a peacock feather design. In Congo tradition, birds represent the souls of the living (MacGaffey, 1986, p. 131), and in this context, the peacock feather design on the bowls could also take on that meaning (Wilkie \& Farnsworth, 2005, pp. 277-279). Did Jack or Sue Eve encounter the bowls with these designs in the market at Nassau and interpret the symbols to have a traditional Congo meaning that was certainly not in the mind of the British potters who created them?

Two examples of embossed British tobacco pipe bowls found at Jack and Sue Eve's house could also convey the same traditional Congo meaning as the cosmogram. These pipes feature a beehive surrounded by flying bees and flowering vines, or at least that would have been the British pipe-maker's interpretation (Figure 4). The beehive however, is reminiscent of the shape of African termite mounds, which, in Congo belief are associated with the dead, while flying insects are associated with the souls of the living (MacGaffey, 1986, pp. $74,263)$. Thus, the juxtaposition of life and death is again communicated through the design on the pipe bowls 
(Wilkie \& Farnsworth, 2005, pp. 290-295). Did Jack and Sue Eve again select British-made goods that in their eyes carried symbols that had a traditional Congo meaning? We shall never know for certain, but the possibility and coincidence of several examples in one household is at least suggestive of the possibility.

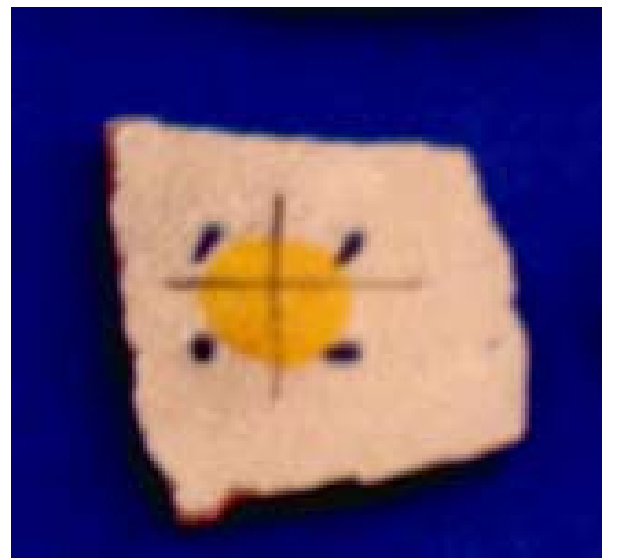

Figure 3. British-made, hand-painted bowl sherd featuring a design that evokes a Bakongo cosmogram.

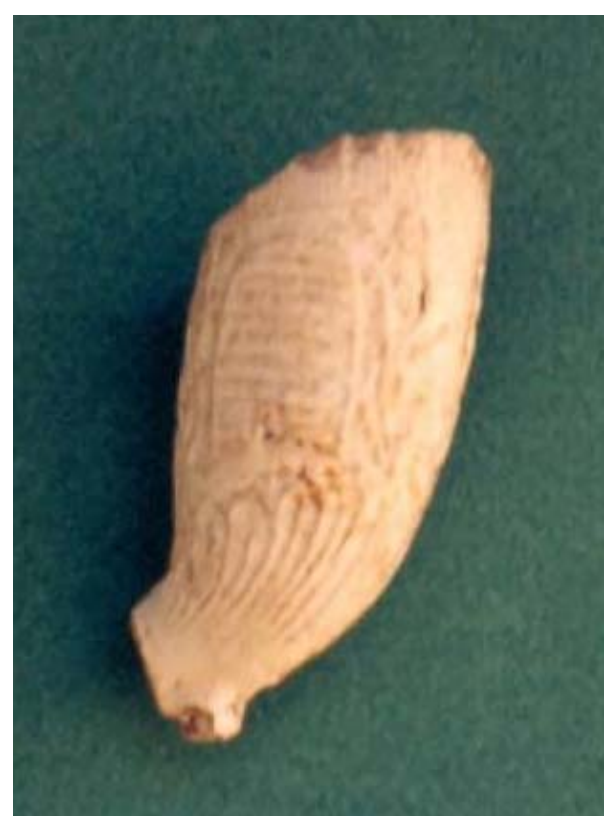

Figure 4. Embossed British tobacco pipe bowl featuring a beehive surrounded by flying bees and flowering vines.

In their consumer selections, the people of Clifton were constructing artifact assemblages that resulted from their memories of their traditional cultural background. In the process, they were creating an Afro-Bahamian aesthetic that would become a tradition for future generations of Bahamians. While the goods were not of their own manufacture, the choices were theirs from the selection available. However, one might argue that there was a limited selection available, and that those of British heritage would have the same colors, designs and vessel forms in their household assemblages.

\section{British Memories and Traditions}

Even though British Loyalists controlled, at least nominally, all elements of the enslaved peoples' lives, they were a small minority on most of the islands of the Bahamas. Many found themselves on very small 
islands separated by hundreds of miles of water from Nassau, the only significant town of the colony. Even on New Providence, home to Nassau, the Anglo population was outnumbered. The island had a large African and African descended population, much of it enslaved, but also with a sizeable number of free people (Craton \& Saunders, 1992, p. 180). Further, Nassau was not central to British colonial interests in the Caribbean, and certainly wasn't like London, or Liverpool, or the many towns in England of similar size.

How do you maintain British identity when you are outnumbered and far from major British communities? As did their enslaved people, the Loyalists relied on their traditions, as they remembered them from Britain, or the North American colonies, where most of them had come from. While their loyalty to the King and family backgrounds may have marked them as British, they were a creolized British population who, in most instances, had spent all or large parts of their lives in the American colonies and were attempting to assert their "Britishness" using their collective memories of British traditions.

Analysis of the ceramics from William Wylly's plantation house found that tablewares dominated the collection. Functional analysis of the ceramics (Table 6) demonstrates that the distribution of vessel forms is similar to that from North American plantation house excavations (e.g. Habicht, 1984, p. 106; Moore, 1985, p. 153; Otto, 1984, pp. 68-69, 166-167). An emphasis on plates (flatwares) over bowls (hollowwares), for example, and almost a third of the collection being tea and coffee wares, matches what is typically seen to be "Anglo" tradition and suggests that the British "Tea Ceremony" was being practiced (Otto, 1984, p. 166; Martin, 1994, p. 172; South, 1977, pp. 40-41, 230; Wilkie \& Farnsworth, 2005, pp. 255-256). However, when one looks at the proportions of plates to bowls, at a 3.5:1 ratio, Wylly had a much higher proportion of plates than most Southern planters, which range from 3:2 to just above 1:1 (Farnsworth, 1999, p. 121), or the houses in the African village at Clifton, which average around 1:1 (Table 7). There may be functional reasons for this, but I think we are seeing the over-exaggeration of a traditional British pattern of behavior in a remote location, and a clear difference between the British and enslaved African assemblages from Clifton.

Table 6

Distribution of Ceramics by Vessel Form and Context

\begin{tabular}{|c|c|c|c|c|c|c|c|c|}
\hline \multirow[b]{2}{*}{ Vessel form } & \multirow[b]{2}{*}{$\begin{array}{l}\text { Wylly's } \\
\text { house } \\
\text { A }\end{array}$} & \multicolumn{5}{|c|}{ Clifton Village } & \multirow[b]{2}{*}{$\begin{array}{l}\text { - Slave/ } \\
\text { apprentice } \\
\text { barracks } \\
\text { N }\end{array}$} & \multirow[b]{2}{*}{$\begin{array}{l}\text { Slave/ } \\
\text { apprentice } \\
\text { barracks } \\
\text { P }\end{array}$} \\
\hline & & $\begin{array}{l}\text { Slave } \\
\text { house/ } \\
\text { kitchen } \\
\text { F }\end{array}$ & $\begin{array}{l}\text { Driver's } \\
\text { house } \\
\text { G }\end{array}$ & $\begin{array}{l}\text { Slave } \\
\text { house } \\
\mathrm{H}\end{array}$ & $\begin{array}{l}\text { Slave } \\
\text { house } \\
\text { I }\end{array}$ & $\begin{array}{l}\text { Slave } \\
\text { house } \\
\text { L }\end{array}$ & & \\
\hline Plates \% & 30.4 & 18.3 & 28.6 & 26.6 & 26.6 & 27.7 & 43.2 & 30.8 \\
\hline Bowls \% & 8.7 & 28.6 & 23.8 & 23.4 & 25.0 & 25.0 & 16.2 & 15.4 \\
\hline Teawares \% & 30.4 & 38.8 & 31.7 & 37.5 & 31.1 & 19.4 & 18.9 & 30.8 \\
\hline Serving vessels \% & 17.4 & 2.0 & 4.8 & 1.6 & 0 & 5.6 & 13.5 & 7.5 \\
\hline Food storage \% & 0 & 0 & 0 & 0 & 0 & 0 & 0 & 7.5 \\
\hline Beverage storage \% & 4.3 & 6.1 & 3.2 & 3.1 & 6.3 & 8.3 & 2.7 & 0 \\
\hline Food preparation \% & 0 & 2.0 & 4.8 & 3.1 & 10.9 & 8.3 & 2.7 & 7.5 \\
\hline Chamber pots \% & 8.7 & 0 & 0 & 1.6 & 0 & 2.8 & 2.7 & 0 \\
\hline Other \% & 0 & 4.0 & 3.2 & 3.2 & 0 & 2.8 & 0 & 0 \\
\hline Number of vessels & 23 & 49 & 63 & 64 & 64 & 36 & 37 & 13 \\
\hline
\end{tabular}


Table 7

Plate to Bowl Ratios by Context

\begin{tabular}{|c|c|c|c|c|c|c|c|c|}
\hline & \multirow[b]{2}{*}{$\begin{array}{l}\text { Wylly's } \\
\text { house } \\
\text { A }\end{array}$} & \multicolumn{5}{|c|}{ Clifton Village } & \multirow[b]{2}{*}{$\begin{array}{l}\text { - Slave/ } \\
\text { apprentice } \\
\text { barracks } \\
\mathrm{N}\end{array}$} & \multirow[b]{2}{*}{$\begin{array}{l}\text { Slave/ } \\
\text { apprentice } \\
\text { barracks } \\
\text { P }\end{array}$} \\
\hline & & $\begin{array}{l}\text { Slave } \\
\text { house/ } \\
\text { kitchen } \\
\text { F }\end{array}$ & $\begin{array}{l}\text { Driver's } \\
\text { house } \\
\text { G }\end{array}$ & $\begin{array}{l}\text { Slave } \\
\text { house } \\
\mathrm{H}\end{array}$ & $\begin{array}{l}\text { Slave } \\
\text { house } \\
\text { I }\end{array}$ & $\begin{array}{l}\text { Slave } \\
\text { house } \\
\text { L }\end{array}$ & & \\
\hline Plates: bowls & $3.5: 1$ & $0.6: 1$ & $1.2: 1$ & $1.1: 1$ & $1.1: 1$ & $1.1: 1$ & $2.7: 1$ & $2.0: 1$ \\
\hline Number of vessels & 9 & 23 & 33 & 32 & 33 & 19 & 22 & 6 \\
\hline
\end{tabular}

Turning to color selection, $60 \%$ of Wylly's hand-painted and factory-turned slipware vessels had blue on them (Table 3). In addition, Wylly had as many transfer-printed vessels and they were all blue on white. Further, he had the same number of shell-edge decorated vessels and $60 \%$ of those where blue on white, and so they further added to the blue on white decoration on Wylly's table (Wilkie \& Farnsworth, 2005, pp. 265, 276). Taken together, approximately $61 \%$ of the ceramic vessels on William Wylly's table had blue decoration. In comparison, in the African village, brown was the most popular color (Wilkie \& Farnsworth, 2005, p. 276). The tradition for blue and white decoration on ceramic tablewares in England began in the late 17th century and was well established in the eighteenth century, following the fashion for Chinese blue and white porcelains (Draper, 1984, pp. 26-32; Noël Hume, 1972, pp. 105-111, 2001, p. 84). William Wylly was signaling his British identity through the color of his ceramics.

\section{Discussion}

As stated in the introduction, in the context of enslavement and the cultural dislocation that accompanied it, memory of traditions became critical in the (re-)creation of tradition in the new geographic and social setting. Individual memory contributed to the practices that created new traditions to be carried forward by subsequent generations. Caribbean cultures like that of the Bahamas, are the unique product of their place and time, and are fluid, dynamic, and subject to the ongoing creativity and innovation of the persons constructing those cultures. Ultimately, the shared experience of race-based enslavement served as a culturally defining and unifying experience for individuals from diverse cultural, ethnic and religious backgrounds. In their consumer selections, the people of Clifton were constructing artifact assemblages that resulted from their memories of their traditional cultural background. Those of African heritage were creating an Afro-Bahamian aesthetic that would become a tradition for future generations of Bahamians. While the goods were not of their own manufacture, the choices were theirs from the selection available. At the same time, those of British heritage, like William Wylly, were signaling their British identity through their ceramic choices.

The concepts of memory and tradition are useful for understanding the creation of Bahamian identities, but the evidence from other Loyalist plantations in the Bahamas highlight a major issue, limited access to consumer goods. Clifton plantation was highly unusual in the Bahamas. Being located on New Providence, it was close to Nassau, the major center for imported goods in the colony, and the major market for the island chain. William Wylly was also a unique character, who despite his many flaws, did provide his enslaved people with both access to that market and the means to acquire goods there. My excavations of two slave cabins at Promised Land plantation on the southwest coast of New Providence only 2 miles from Clifton, illustrates the difference that the attitudes and policies of the plantation owner could have on the enslaved people's access to consumer goods. The excavations recovered a ceramic assemblage that was composed of almost $90 \%$ plain, undecorated 
British earthenware ceramics, with the remainder being sherds from patterns also recovered at the planter's house (Farnsworth, 1999, p. 122). In this case, owner William Moss, who was also one of the major slave importers to the Bahamas and an avowed enemy of William Wylly, supplied the cheapest possible ceramics to the enslaved people. Apparently they had no direct access to the market in Nassau and no there is no record that Moss provided them with any means to acquire good if they did go there. In doing so, Moss denied the enslaved people the opportunity to express their traditions and heritage through their use of these material goods (Farnsworth, 1999, p. 124).

Wylly and Moss probably represent two ends of a continuum of planter attitudes to slavery and the treatment of the enslaved. On New Providence, the market in Nassau flourished throughout the Loyalist period and most enslaved Africans on the island probably had some degree of access to goods from it either directly or indirectly. Certainly free Blacks and the many enslaved Africans who worked in the town would have had access to consumer goods from it or directly from merchants. However, unlike many of the Caribbean islands, the isolated Bahamian islands had no tradition of internal markets where enslaved peoples could trade for goods of their own choosing. Instead, in most cases, they were dependent upon the limited range of goods brought to the island by the planters. For example, At Wade's Green plantation on North Caicos, a collection of ceramics was recovered from a slave house, but the composition of vessel forms matches Anglo-American usage and half of the vessels were plain, undecorated British earthenwares. The assemblage therefore reflects planter Wade Stubbs provisioning his enslaved people with ceramics, rather than their own consumer choices (Farnsworth, 1996, 1999, p. 122).

The concepts of memory and tradition can be useful in understanding the creation of identity from archaeological assemblages, but only in those settings where non-perishable material culture survives in the archaeological record for analysis. In the case of the Bahamas, very little of the non-perishable material culture that is found archaeologically was made by the enslaved Africans. The majority of the materials that survive were made in Britain and imported to the colony. It is through the enslaved Africans' selections from these imported goods that we can learn something of their efforts to recreate and express their African traditions based on their memories of the traditions they, or their parents, had practiced in Africa.

\section{Acknowledgements}

An earlier version of this paper was presented at the Connecting Continents Conference, Curacao, in November 2015. The archaeological research at Clifton was carried out jointly by the author and Dr. Laurie A. Wilkie. I wish to acknowledge Dr. Wilkie's considerable contributions to that research and the subsequent publications. I also thank the students in the Louisiana State University and University of California Archaeology Field Schools; The Department of Geography \& Anthropology, Louisiana State University; The Archaeological Research Facility, University of California, Berkeley; The Government of the Commonwealth of the Bahamas; Dr. Gail Saunders and the staff of the Department of Archives, Nassau; The Bahamas National Trust; The Maillis Family of Adelaide, New Providence; and the people of the Bahamas. All errors and omissions are the responsibility of the author.

\section{References}

Agorsah, E. K. (1994). Maroon heritage: Archaeological, ethnographic and historical perspectives. Kingston, Jamaica: Canoe Press. 
Agorsah, E. K. (1999). Ethnoarchaeological consideration of social relationship and settlement patterning among Africans in the Caribbean diaspora. In J. B. Haviser (Ed.), African sites archaeology in the Caribbean (pp. 38-64). Princeton, N.J.: Markus Wiener Publishers \& Kingston, Jamaica: Ian Randle Publishers, Kingston.

Aniakor, C. (1996). Household objects and the philosophy of Igbo social space. In M. J. Arnoldi, C. M. Geary, and K. L. Hardin (Eds.), African material culture (pp. 214-242). Bloomington: Indiana University Press.

Armstrong, D. V. (1990). The Old Village and the Great House: An archaeological and historical examination of Drax Hall Plantation, St. Ann's Bay, Jamaica. Urbana: University of Illinois Press.

Armstrong, D. V. (1998). Cultural transformation within enslaved laborer communities in the Caribbean. In James G. Cusick (Ed.), Studies in culture contact: Interaction, culture change, and archaeology (pp. 378-401). Carbondale: Center for Archaeological Investigations Occasional Paper, no. 25. Southern Illinois University.

Armstrong, D. V. (200). Creole transformation from slavery to freedom: Historical archaeology of the East End Community, St. John, Virgin Islands. Gainesville: University Press of Florida.

Behrendt, S. D. (1997). The annual volume and regional distribution of the British slave trade, 1780-1907. Journal of African History, 38, 187-211.

Colonial Office Records [CO]. (1817). Petition. William Wylly to H. R. H. Prince Regent, October 7, CO 23/65:95.

Comaroff, J., \& John C. (1993). Modernity and its malcontents: Ritual and power in postcolonial Africa. Chicago: University of Chicago Press.

Craton, M., \& Gail, S. (1992). Islanders in the stream: A history of the Bahamian people. From aboriginal times to the end of slavery (Vol. 1). Athens: University of Georgia Press.

Creel, M. W. (1988). “A peculiar people”: Slave religion and community-culture among the Gullahs. New York: New York University Press.

Curtin, P. D. (1967). Africa remembered: Narratives by West Africans from the era of the slave trade. Baltimore, MD: Johns Hopkins University Press.

Curtin, P. D. (1972). The Atlantic slave trade: A census. Madison: University of Wisconsin Press.

Curtin, P. D. (1976). Measuring the Atlantic slave trade once again: A comment by Philip D. Curtin. Journal of African History, 17(4), 595-627.

Deagan, K. (1983). Spanish St. Augustine: The archaeology of a colonial Creole community. New York: Academic Press.

Deetz, J. F. (1993). Flowerdew hundred: The archaeology of a Virginia plantation, 1619-1864. Charlottesville: University Press of Virginia.

Draper, J. (1984). Post-Medieval pottery 1650-1800. England: Shire Publications, Aylesbury.

Edwards-Ingram, Y. (2001). African American medicine and the social relations of slavery. In C. E. Orser (Ed.), Race and the archaeology of identity (pp. 34-53). Salt Lake City: University of Utah Press.

Eltis, D., \& Martin, H. (Eds.). (2009). Voyages: Trans-Atlantic slave trade database. Emory University, Atlanta, GA. Retrieved February 24, 2016, from http://www.slavevoyages.org

Eltis, D., Stephen, B., David, R., \& Herbert, S. K. (1999). The transatlantic slave trade. Cambridge, England: Cambridge University Press.

Eneas, C. W. (1976). Bain Town. Nassau, Bahamas: Cleveland and Muriel Eneas.

Farnsworth, P. (1996). The influence of trade on Bahamian slave culture. Historical Archaeology, 30(4), 1-23.

Farnsworth, P. (1999). From the past to the present: An exploration of the formation of African Bahamian identity during enslavement. In J. B. Haviser (Ed.), African sites archaeology in the Caribbean (pp. 94-130). Princeton, N.J.: Markus Wiener Publishers, \& Kingston, Jamaica: Ian Randle Publishers.

Farnsworth, P. (2001). "Negroe houses built of stone besides others Watl'd and plaistered”: The creation of a Bahamian tradition. In P. Farnsworth (Ed.), Island lives: Historical archaeologies of the Caribbean (pp. 234-271). Tuscaloosa: University of Alabama Press.

Fennell, C. (2003). Group identity, individual creativity and symbolic generation in a BaKongo diaspora. International Journal of Historical Archaeology, 7(1), 1-31.

Fennell, C. (2007). Crossroads and cosmologies: Diasporas and ethnogenesis in the new world. Gainesville: University Press of Florida.

Fennell, C. (2011). Literate inversions and cultural metaphors in Edgefield stoneware. Historical Archaeology, 45(2), 56-162.

Ferguson, L. (1992). Uncommon ground. Washington, D.C.: Smithsonian Institution Press. 
Ferguson, L. (1999). "The cross is a magic sign”: Marks on eighteenth-century bowls from South Carolina. In T. A. Singleton (Ed.), “I, too, am America”: Archaeological studies of African-American life (pp. 116-131). Charlottesville: University Press of Virginia.

Ferguson, L. (2011). Crosses, secrets, and lies: A response to J. W. Joseph’s ““...All of cross’-African potters, marks, and meanings in the folk pottery of the Edgefield District, South Carolina.” Historical Archaeology, 45(2), 163-165.

Gilroy, P. (1993). The Black Atlantic: Modernity and double consciousness. Cambridge, MA: Harvard University Press.

Gomez, M. (1998). Exchanging our country marks: The transformation of African identities in the colonial and antebellum South. Chapel Hill: University of North Carolina Press.

Goucher, C. (1999). African-Caribbean metal technology: Forging cultural survivals in the Atlantic World. In J. B. Haviser (Ed.), African sites archaeology in the Caribbean (pp. 143-156). Princeton, N.J.: Markus Wiener Publishers, \& Kingston, Jamaica: Ian Randle Publishers.

Gundaker, G. (1998). Signs of Diaspora/Diaspora of signs. New York: Oxford University Press.

Gundaker, G. (2011). The Kongo cosmogram in historical archaeology and the moral compass of Dave the Potter. Historical Archaeology, 45(2), 176-183.

Habicht, J. A. (1984). The "Root Cellar” at Shirley. In T. R. Reinhart (Ed.), The archaeology of Shirley plantation (pp. 84-155). Charlottesville: University Press of Virginia.

Handler, J. S. (1996). A prone burial from a plantation slave cemetery in Barbados, West Indies: Possible Evidence for an African-type witch or other negatively viewed person. Historical Archaeology, 30(3), 76-86.

Handler, J. S., \& Frederick, W. L. (1978). Plantation slavery in Barbados: An archaeological and historical investigation. Cambridge, MA: Harvard University Press.

Haviser, J. B. (1999a). African sites archaeology in the Caribbean. Princeton, N.J.: Markus Wiener Publishers, \& Kingston, Jamaica: Ian Randle Publishers.

Haviser, J. B. (1999b). Identifying a post-emancipation (1863-1940) African-Curaçaoan material culture assemblage. In J. B. Haviser (Ed.), African sites archaeology in the Caribbean (pp. 221-263). N.J.: Markus Wiener Publishers, \& Kingston, Jamaica: Ian Randle Publishers.

Herskovits, M. (1971). Life in a Haitian valley. New York: Doubleday.

Herskovits, M. (1990). Myth of the Negro past. Boston, MA: Beacon Press.

Higman, B. W. (1984). Slave populations of the British Caribbean, 1807-1834. Baltimore, MD: Johns Hopkins University Press.

Higman, B. W. (1998). Montpelier, Jamaica: A plantation community in slavery and freedom, 1739-1912. Kingston, Jamaica: The Press University of the West Indies.

Inikori, J. E. (1976). Measuring the Atlantic slave trade: A reminder by J. E. Inikori. Journal of African History, 17(4), 607-621.

Joseph, J. W. (2011). “...All of Cross”-African potters, marks, and meanings in the folk pottery of the Edgefield District, South Carolina. Historical Archaeology, 45(2), 134-155.

Joyner, C. (1984). Down by the riverside: A South Carolina Slave Community. Urbana: University of Illinois Press.

Leone, M. P., \& Gladys-Marie, F. (1999). Conjuring in the big house kitchen: An interpretation of African-American belief systems based on the uses of archaeology and folklore sources. Journal of American Folklore, 112(445), 372-403.

Lightfoot, K. (1995). Culture contact studies: Redefining the relationship between prehistoric and historic archaeology. American Antiquity, 60, 199-217.

Lightfoot, K., Antoinette, M., \& Ann M. S. (1997). Daily practice and material culture in pluralistic social settings: An archaeological study of culture change and persistence from fort Ross, California. American Antiquity, 63, 199-222.

Littlefield, D. (1981). Rice and slaves: Ethnicity and the slave trade in colonial South Carolina. Baton Rouge: Louisiana State University Press.

MacGaffey, W. (1986). Religion and society in central Africa. Chicago: University of Chicago Press.

Mama, A. (1995). Beyond the masks: Race, gender, and subjectivity. London: Routledge.

Manning, P. (1992). The slave trade: The formal demography of a global system. In J. E. Inikori and S. Engerman (Eds.), The Atlantic slave trade: Effects on economies, societies, and peoples in Africa, the Americas, and Europe (pp. 117-145). Durham, NC: Duke University Press.

Martin, A. S. (1994). "Fashionable sugar dishes, latest fashion ware" The creamware revolution in the eighteenth-century Chesapeake. In P. A. Shackel and B. J. Little (Eds.), Historical archaeology of the Chesapeake (pp. 169-187). Washington, D.C.: Smithsonian Institution Press.

Mintz, S. (1974). Caribbean transformations. New York: Columbia University Press. 
Mintz, S., \& Richard, P. (1976). The birth of African American culture: An anthropological perspective. Boston, MA: Beacon Press.

Moore, S. M. (1985). Social and economic status on the coastal plantation: An archaeological perspective. In T. A. Singleton (Ed.), The archaeology of slavery and plantation life (pp. 141-160). Orlando, FL: Academic Press.

Noël Hume, I. (1972). A guide to artifacts of colonial America. New York: Alfred A. Knopf.

Noël Hume, I. (2001). If these pots could talk. Milwaukee, WI: The Chipstone Foundation.

Otto, J. S. (1984). Cannon's point plantation 1794-1860: Living conditions and status patterns in the old south. Orlando, FL: Academic Press.

Pauketat, T. R. (Ed.). (2001). The archaeology of traditions: Agency and history before and after Columbus. Gainesville: University Press of Florida.

Posnansky, M. (1999). West African reflections on African-American archaeology. In T. A. Singleton (Ed.), “I, too, am America”: Archaeological studies of African-American life (pp. 21-38). Charlottesville: University Press of Virginia.

Price, S., \& Richard, P. (1980). Afro-American arts of the Suriname rain forest. Berkeley and Los Angeles: University of California Press.

Price, S., \& Richard, P. (1999). Maroon arts: Cultural vitality in the African Diaspora. Boston: Beacon Press.

Pulsipher, L. (1993). Changing roles in the life cycles of women in traditional West Indian houseyards. In J. J. Momsen (Ed.), Women and change in the Caribbean (pp. 50-64). Bloomington: Indiana University Press.

Register of Slaves, Bahamas. (1821). Return of William Wylly. Department of Archives, Nassau, Bahamas.

Register of Slaves, Bahamas. (1825). Return of William Wylly. Department of Archives, Nassau, Bahamas.

Richardson, D. (1989). Slave exports from West and West-central Africa, 1780-1810: New estimates of volume and distribution. Journal of African History, 30, 1-22.

Singleton, T. A. (1999). "I, too, am America”: Archaeological studies of African-American life. Charlottesville: University Press of Virginia.

Singleton, T. A. (Ed.). (1985). The archaeology of slavery and plantation life. Orlando, FL: Academic Press.

South, S. (1977). Method and theory in historical archeology. New York: Academic Press.

Steen, C. (2011). Cosmograms, crosses, and Xs: Context and inference. Historical Archaeology, 45(2), 166-175.

Thompson, R. F. (1974). African art in motion: Icon and act. Washington, D.C.: National Gallery of Art, \& Los Angeles: Frederick S. Wight Art Gallery, University of California.

Thompson, R. F. (1981). Four moments of the sun. Washington, D.C.: National Art Gallery.

Thompson, R. F. (1983). Flash of the spirit: African and Afro-American art and philosophy. New York: Vintage Books.

Thompson, R. F. (1993). Face of the Gods: Art and altars of Africa and the African Americas. New York: Museum for African Art.

Vlach, J. M. (1986). The shotgun house: An African architectural legacy. In D. Upton and J. M. Vlach (Eds.), Common places: Readings in American vernacular architecture (pp. 58-78). Athens: University of Georgia Press.

Walsh, L. S. (1997). From calabar to carter's grove: The history of a Virginia slave community. Charlottesville: University Press of Virginia.

Wilkie, L. A. (2000). Creating freedom: Material culture and African American identity at Oakley plantation, Louisiana, 1840-1950. Baton Rouge: Louisiana State University Press.

Wilkie, L. A. (2001). Methodist intentions and African sensibilities: The victory of African consumerism over planter paternalism at a Bahamian plantation. In P. Farnsworth (Ed.), Island lives: Historical archaeologies of the Caribbean (pp. 272-300). Tuscaloosa: The University of Alabama Press.

Wilkie, L. A. (2003). The archaeology of mothering: An African-American midwife's tale. New York: Routledge.

Wilkie, L. A., \& Paul, F. (2005). Sampling many pots: An archaeology of memory and tradition at a Bahamian plantation. Gainesville: University Press of Florida.

Wylly, W. (1815). Regulations for the government of the slaves at Clifton and Tusculum in New Providence. CO 23/67:153-160.

Yentsch, A. E. (1994). A Chesapeake family and their slaves. Cambridge: Cambridge University Press. 